\title{
HUBUNGAN ANTAR ORGANISASI DALAM SISTEM PENGORGANISASIAN PENGENDALIAN KEBAKARAN HUTAN/LAHAN DI INDONESIA
}

\author{
Study on Interorganizational Relationships in the Organizing System of \\ Forest/Land Fire Control in Indonesia \\ Erly Sukrismanto ${ }^{1)}$, Hadi S. Alikodra ${ }^{2)}$, Bambang H. Saharjo ${ }^{3)}$, \\ dan/and Priyadi Kardono ${ }^{4}$ \\ ${ }^{1)}$ Direktorat Pengendalian Kebakaran Hutan, Gedung Manggala Wanabakti Blok VII Lantai 13, \\ Jl. Gatot Subroto, Jakarta 10270, HP: +62818161166, e-mail: erlyskm@yahoo.com \\ ${ }^{2)}$ Departemen Konservasi Sumber Daya Hutan dan Ekowisata, Fakultas Kehutanan, IPB, Bogor, \\ HP: +6281210494949, e-mail: halikodra@wwf.or.id \\ ${ }^{3)}$ Departemen Silvikultur, Fakultas Kehutanan, IPB, Bogor. \\ HP: +628161948064, e-mail: bhsaharjo@gmail.com \\ ${ }^{4}$ Deputi Bidang Survei Dasar dan Sumber Daya Alam, Bakosurtanal, \\ J1. Raya Jakarta-Bogor KM 46, Cibinong 16911 \\ HP: +62816731777, e-mail: priyadi.kardono@gmail.com
}

Naskah masuk : 3 Januari 2011; Naskah diterima : 7 Juni 2011

\begin{abstract}
Forest/land fire is one of the main causes of global climate change. Until recently the management of forest/land fire control in Indonesia is still ineffective due among others to the weakness of its fire control organization system. The coordination among the involved organizations is considered ineffectual. This research aims at finding empirical evidences to prove the opinion. An analysis method using the three aspects of integrative coordination including service delivery, administrative and planning is employed. The results of study on 42 organizations at national, provincial, and district levels indicate that a relatively good coordination has been existent among the national level organizations. While at provincial and district levels, although the coordination in the research sites is still insubstantial, Riau demonstrates a better situation than West Kalimantan in the coordination. The relationships among Riau's organizations at each of the provincial and district levels and vertically between those levels as well as with the national one have been existent. While in West Kalimantan such relationships present in only among a few organizations at the same level and absent in between levels. The difference in the basis of departmentation seems to be the reason. The study thus provides evidence that the coordination among the organizations involved in forest/land fire control has been inadequate so that management of forest/land fires is still ineffective.
\end{abstract}

\section{Keywords: Coordination, fire control organization, institution}

\begin{abstract}
ABSTRAK
Kebakaran hutan/lahan merupakan salah satu sumber penyebab utama perubahan iklim global. Sampai sekarang kebakaran hutan/lahan di Indonesia belum dapat diatasi secara optimal, disebabkan salah satunya oleh sistem pengorganisasian pengendalian kebakaran hutan/lahan yang masih lemah. Studi ini bertujuan untuk menganalisis hubungan antar organisasi di dalam sistem pengorganisasian pengendalian kebakaran hutan/lahan. Metode penelitian yang digunakan adalah analisis jejaring koordinasi dengan kajian terhadap tiga aspek yaitu bantuan layanan, administratif, dan perencanaan pada 42 organisasi tingkat nasional, provinsi dan kabupaten/kota. Hasil analisis menemukan bahwa koordinasi antar organisasi pada tingkat nasional relatif baik, sedangkan koordinasi di tingkat provinsi dan kabupaten/kota masih lemah. Koordinasi secara horizontal pada satu tingkatan maupun secara vertikal antar tingkatan di Riau telah terjalin di antara lebih banyak organisasi dibandingkan dengan di Kalimantan Barat, di mana
\end{abstract}


koordinasi secara horizontal maupun secara vertikal belum terjalin. Penelitian ini membuktikan secara empirik bahwa koordinasi antar organisasi dalam pengendalian kebakaran hutan/lahan di Indonesia masih lemah, sehingga kebakaran hutan/lahan belum dapat terkelola dengan baik.

\section{Kata kunci : Koordinasi, pengendalian kebakaran, institusi}

\section{PENDAHULUAN}

Kebakaran hutan/lahan di Indonesia berdampak sangat luas terhadap berbagai aspek, baik ekologi dan lingkungan maupun ekonomi, sosial, dan politik. DFID dan World Bank (2007) menyatakan bahwa kebakaran hutan/lahan di Idonesia telah melepaskan sekitar 1400 metrik ton karbon dioksida per tahun, jauh di atas emisi dari sektor energi yang hanya sekitar 275 metrik ton. Bappenas (1999) mencatat kerugian akibat dari kebakaran hutan/lahan tahun 1997-1998 sekitar US\$ 9.3 milyar atau Rp 5,96 trilyun yang setara dengan $70 \%$ dari nilai PDB sektor Kehutanan tahun 1997.

Berbagai studi menunjukkan bahwa masalah kebakaran hutan/lahan di Indonesia tidak hanya bersifat teknis yang berkaitan dengan penyebab fisik di lapangan yang berkaitan dengan ketersediaan unsur-unsur segitiga api (bahan bakar, oksigen, dan panas) yang berlimpah (Chandrasekharan, 1999), melainkan juga berkaitan dengan sosial politik (Doscemascolo, 2004) dan kelembagaan pengendalian kebakarannya (Simorangkir, 2001; Kartodihardjo, 2006). Kajian terhadap aspek sosial politik dan kelembagaan lebih banyak menyoroti lemahnya aturan main dalam pelaksanaan serta penegakan sanksi, sementara peran masing-masing organisasi/institusi pengendalian kebakaran kurang mendapat perhatian.

Data besarnya jumlah akumulasi titik panas (hotspot) merupakan indikator tingginya frekuensi terjadinya kebakaran hutan/lahan (Hiroki dan Prabowo, 2003; Suprayitno dan Syaufina, 2008). Selama 10 tahun terakhir jumlah rata-rata titik panas per tahun masih di atas 50 ribu titik. Hal ini dapat mengindikasikan bahwa belum efektifnya organisasi pengendalian kebakaran hutan/lahan dalam menangani kebakaran hutan/lahan dan faktor-faktor penyebabnya selama ini.

Organisasi pengendalian kebakaran hutan/lahan melibatkan banyak instansi atau organisasi pemerintah, baik di tingkat nasional, provinsi, maupun kabupaten/kota. Pelibatan di antara pihak-pihak tersebut memerlukan suatu sistem pengorganisasian yang bekerja secara integratif dan harmonis agar efektif dan efisien (Siswanto, 2009). Kelemahan pengorganisasian dapat disebabkan oleh berbagai faktor antara lain (1) belum jelasnya peranan dalam pengorganisasian (Wehmeyer et al., 2001; Colman dan Han, 2005), (2) belum optimalnya hubungan antara organisasi-organisasi yang terlibat (Mulford dan Klonglan, 1982; Bolland dan Wilson, 1994; Malone et al., 1999; Wehmeyer et al., 2001) dan (3) belum efektifnya organisasi yang terlibat (Young Lee dan Whitford, 2008). Tulisan ini menguraikan hasil studi terhadap faktor kedua, yakni hubungan antar organisasi.

Hubungan antar organisasi dapat berupa kerja sama, kompetisi, atau perseteruan (Mooi, 2007; Faerman et al., 2001; Mulford dan Klonglan, 1982). Hubungan dalam pengorganisasian kebakaran hutan/lahan di Indonesia adalah kerja sama dalam bentuk koordinasi, baik pada satu level maupun antar level pemerintahan. Penelitian ini bertujuan untuk mengkaji tingkat keharmonisan hubungan antar para pihak atau institusi dalam upaya merancang model sistem pengorganisasian pengendalian kebakaran hutan/lahan di Indonesia.

\section{METODE PENELITIAN}

\section{A. Lokasi dan Waktu Penelitian}

Penelitian ini dilakukan terhadap organisasi-organisasi di tingkat nasional di Jakarta dan sekitarnya, di tingkat provinsi di Riau dan Kalimantan Barat, dan di tingkat kabupaten/kota di Kota Dumai dan Kabupaten Indragiri Hulu, Provinsi Riau dan Kabupaten Ketapang dan Kabupaten Kubu Raya, Provinsi Kalimantan Barat. Pengumpulan data dilaksanakan pada bulan Februari sampai dengan Juli 2010.

\section{B. Teknik Pengambilan Contoh}

Hasil identifikasi mendapati sebanyak 42 organisasi yang terlibat dalam pengendalian kebakaran hutan/lahan dari semua tingkatan. 
Pengambilan contoh dilakukan secara purposif di mana responden yang dipilih terdiri dari para pejabat di tingkat eselon IV sampai dengan eselon II yang sering ditugasi atau bidang tugasnya berkaitan dengan pengendalian kebakaran hutan/lahan pada setiap organisasi tersebut. Jumlah responden adalah 282 orang terdiri dari 42 pejabat eselon II, 84 pejabat eselon III, dan 156 pejabat eselon IV.

\section{Pengumpulan dan Analisis Data}

Data yang dikumpulkan terdiri atas data primer dan data sekunder. Data primer berupa pendapat responden yang merupakan parameter yang dapat menunjukkan persepsi para pimpinan organisasi/instansi mengenai hubungan antara organisasinya dengan organisasi-organisasi lain. Pengumpulan data dilakukan dengan menggunakan angket yang diadopsi dan dimodifikasi dari Bolland dan Wilson (1994). Pertanyaan angket tersebut berupa: (1) Client referrals (rujukan klien) yang digunakan untuk mengetahui ada tidaknya hubungan antara institusi dalam memberikan dan menerima bantuan layanan; (2) Hubungan administrasi yang melibatkan transaksi sumber daya dianalogikan dengan bantuan organisasi lain dalam mencapai tujuan, dan (3) Perkenalan untuk mengetahui hubungan daari aspek perencanaan.

Data sekunder diperoleh dari tiap organisasi yang diamati berupa dokumen profil organisasi yang berkenaan dengan hubungan dan kerja sama organisasi tersebut dengan organisasiorganisasi lain dan data keterlibatannya dalam pengendalian kebakaran hutan/lahan. Di tingkat provinsi, organisasi yang menangani kebakaran hutan/lahan adalah Pusat Pengendalian Kebakaran Hutan dan Lahan (Pusdalkarhutlada), sedangkan di kabupaten/kota adalah Satuan Pelaksana Pengendalian Kebakaran Hutan dan Lahan (Satlakdalkarhutla).

Pengolahan dan analisis data menggunakan prosedur yang diadopsi dari coordination network analysis (Bolland dan Wilson, 1994) sebagai berikut:

1. Bantuan Layanan. Analisis ini menggunakan kombinasi jawaban responden atas pertanyaan apakah organisasinya (a) memberi bantuan layanan kepada dan/atau (b) menerima bantuan layanan dari organisasi lain. Analisis ini adalah untuk memperoleh sebuah ukuran dari bantuan layanan yang terkonfirmasi.

2. Administratif. Analisis ini menggunakan jawaban atas pertanyaan tentang sejauh mana organisasi lain telah membantu organisasi responden dalam mencapai tujuan.

3. Planning. Analisis ini melihat kaitan antara orang-orang dari dua organisasi dengan cara meminta responden menuliskan nama orangorang yang ia kenal dari organisasi lain. Jika sedikitnya satu orang dari organisasi tersebut mengenal sedikitnya satu orang dari organisasi lain, maka dapat dikatakan bahwa terdapat hubungan antara kedua organisasi tersebut.

\section{HASIL DAN PEMBAHASAN}

\section{A. Bantuan Layanan}

Hasil analisis menunjukkan bahwa organisasi yang saling berhubungan di dalam memberikan bantuan layanan di tingkat nasional hanya 9 organisasi dari 22 organisasi yang terbentuk. Salah satu di antara contoh matrik hubungan bantuan layanan di antara organisasi tertera pada Gambar 1. Walaupun banyak organisasi yang saling berhubungan dalam aspek pelayanan, namun bantuan yang diberikan atau diterima tidak terkonfirmasi oleh organisasi lain. Ada dua institusi yang memiliki hubungan layanan terkonfirmasi terbanyak yaitu LAPAN dan Bakosurtanal seperti terlihat pada Gambar 2. Kedua organisasi tersebut lebih banyak memberikan layanan dalam bentuk informasi.

Gambar 2 juga memperlihatkan bahwa di tingkat provinsi dan tingkat kabupaten/kota, hubungan dalam aspek bantuan layanan masih relatif terbatas. Sebagai contoh, Dishut Provinsi Riau yang dalam struktur Pusdalkarhutla memegang peranan penting sebagai koordinator bidang pemadaman justru tidak memiliki hubungan bantuan layanan yang terkonfirmasi dari manapun kecuali dari Dishutbun Kab. Inhu. Kondisi ini menunjukkan lemahnya koordinasi oleh Dishut Provinsi Riau dalam menggalang bantuan dari berbagai pihak, padahal dengan kapasitas organisasi yang masih lemah, upaya pemadaman masih sangat memerlukan bantuan dari berbagai pihak. Kondisi serupa juga terjadi di Kalbar, bahkan di daerah tersebut tidak ada satupun hubungan bantuan layanan yang terkonfirmasi di antara organisasi-organisasi di tingkat provinsi dan juga di tingkat kabupaten/ kota serta antar tingkatan. Kondisi ini menjadi salah satu penyebab masih tingginya frekuensi kebakaran hutan/lahan di daerah tersebut seperti digambarkan oleh jumlah akumulasi titik panas 
(hotspot) yang masih relatif tinggi. Di Riau, misalnya, jumlah hotspot rata-rata per tahun selama 10 tahun terakhir masih 7.897 titik, sedangkan Kalbar sebanyak 9.221 titik/tahun. Hal ini tampaknya dipengaruhi oleh sistem pengorganisasian yang diterapkan dalam Pusdalkarhutla di mana departementasi didasarkan pada wilayah pemangkuan kawasan.

Sistem pengorganisasian yang ada saat ini mengandalkan keterlibatan banyak pihak, tetapi hubungan perbantuan layanan masih kurang. Hal ini terjadi karena peranan-peranan dalam koordinasi (Wehmeyer et al., 2001; Malone et al., 1999) belum terdefinisikan dengan jelas. Di samping itu, konsep kerja sama (Mulford dan Klonglan, 1982) dan concept of capability (Ulrich, 1997) belum diterapkan dengan benar. Menurut konsep tersebut organisasi seharusnya lebih fokus membangun kapabilitasnya sendiri, tetapi yang terjadi justru organisasi-organisasi tersebut lebih mengandalkan bantuan sumber daya dari organisasi lain. Kondisi tersebut membuat kinerja dalam pengendalian kebakaran hutan/lahan selama ini relatif masih rendah di semua tingkatan. Untuk itu, penetapan tugas (Malone et al., 1999) harus diperjelas di dalam struktur dan uraian tugas organisasi yang akan dibangun.

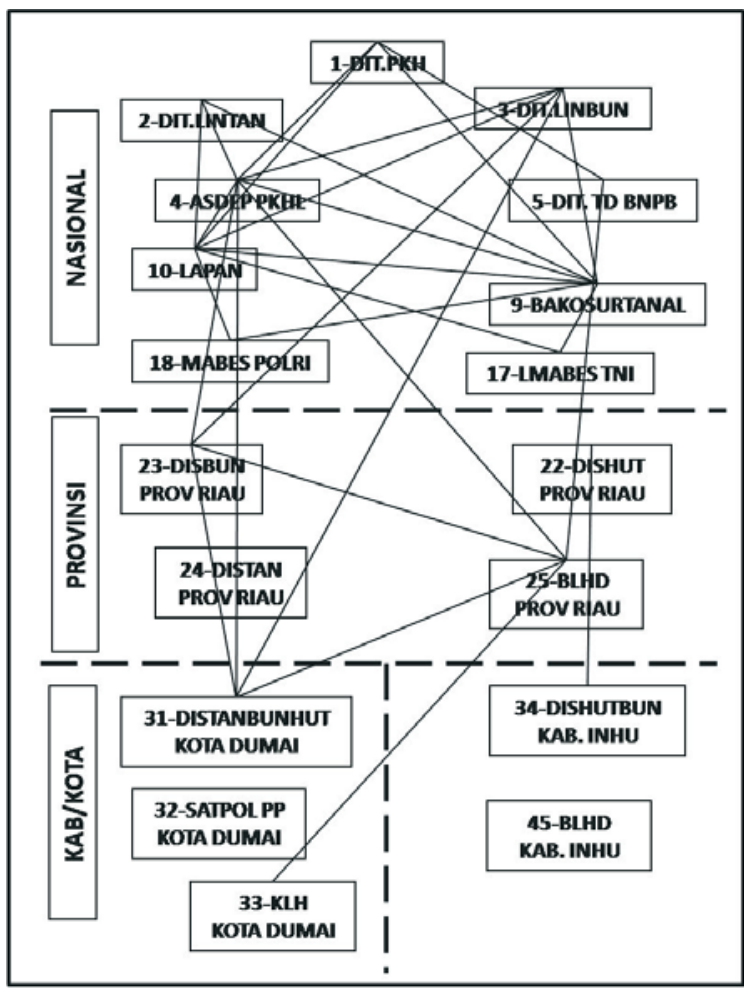

Gambar(Figure)2. Diagram hubungan antar organisasi dari aspek bantuan layanan di Riau (Inter-organizational relationships on the aspect of service delivery in Riau)

Gambar(Figure) 1. Contoh sebagian matriks hubungan antar organisasi dalam bantuan layanan di tingkat nasional (A part of the matrix indicating the interorganizational relationships in service delivery at National level)

\begin{tabular}{|c|l|c|c|c|c|c|c|c|c|c|c|c|c|c|c|c|c|c|c|}
\hline No. & \multicolumn{1}{|c|}{ Nama Organisasi } & 1 & 2 & 3 & 4 & 5 & 6 & 7 & 8 & 9 & 10 & 11 & 12 & 13 & 14 & 15 & 16 & 17 & 18 \\
\hline 1 & Dit. PKH & & 0 & 0 & $\mathbf{1}$ & $\mathbf{1}$ & 0 & 0 & 0 & $\mathbf{1}$ & $\mathbf{1}$ & 0 & 0 & 0 & 0 & 0 & 0 & 0 & 0 \\
\hline 2 & Dit. Lintan & 0 & & 0 & $\mathbf{1}$ & 0 & 0 & 0 & 0 & $\mathbf{1}$ & $\mathbf{1}$ & 0 & 0 & 0 & 0 & 0 & 0 & 0 & 0 \\
\hline 3 & Dit. Linbun & 0 & 0 & & $\mathbf{1}$ & 0 & 0 & 0 & 0 & $\mathbf{1}$ & $\mathbf{1}$ & 0 & 0 & 0 & 0 & 0 & 0 & 0 & 0 \\
\hline 4 & Asdep PKHL & $\mathbf{1}$ & $\mathbf{1}$ & $\mathbf{1}$ & & 0 & 0 & 0 & 0 & $\mathbf{1}$ & $\mathbf{1}$ & 0 & 0 & 0 & 0 & 0 & 0 & 0 & 0 \\
\hline 5 & BNPB & 0 & 0 & 0 & 0 & & 0 & 0 & 0 & 0 & 0 & 0 & 0 & 0 & 0 & 0 & 0 & 0 & 0 \\
\hline 6 & Bappenas & 0 & 0 & 0 & 0 & 0 & & 0 & 0 & 0 & 0 & 0 & 0 & 0 & 0 & 0 & 0 & 0 & 0 \\
\hline 7 & BMKG & 0 & 0 & 0 & 0 & 0 & 0 & & 0 & 0 & 0 & 0 & 0 & 0 & 0 & 0 & 0 & 0 & 0 \\
\hline 8 & Basarnas & 0 & 0 & 0 & 0 & 0 & 0 & 0 & & 0 & 0 & 0 & 0 & 0 & 0 & 0 & 0 & 0 & 0 \\
\hline 9 & Bakosurtanal & $\mathbf{1}$ & $\mathbf{1}$ & $\mathbf{1}$ & $\mathbf{1}$ & 0 & 0 & 0 & 0 & & 1 & 0 & 0 & 0 & 0 & 0 & 0 & $\mathbf{1}$ & $\mathbf{1}$ \\
\hline 10 & LAPAN & $\mathbf{1}$ & $\mathbf{1}$ & $\mathbf{1}$ & $\mathbf{1}$ & 0 & 0 & 0 & 0 & 1 & & 0 & 0 & 0 & 0 & 0 & 0 & $\mathbf{1}$ & $\mathbf{1}$ \\
\hline 11 & Depdagri & 0 & 0 & 0 & 0 & 0 & 0 & 0 & 0 & 0 & 0 & & 0 & 0 & 0 & 0 & 0 & 0 & 0 \\
\hline 12 & Deplu & 0 & 0 & 0 & 0 & 0 & 0 & 0 & 0 & 0 & 0 & 0 & & 0 & 0 & 0 & 0 & 0 & 0 \\
\hline 13 & Depsos & 0 & 0 & 0 & 0 & 0 & 0 & 0 & 0 & 0 & 0 & 0 & 0 & & 0 & 0 & 0 & 0 & 0 \\
\hline 14 & Depkes & 0 & 0 & 0 & 0 & 0 & 0 & 0 & 0 & 0 & 0 & 0 & 0 & 0 & & 0 & 0 & 0 & 0 \\
\hline 15 & Dephub & 0 & 0 & 0 & 0 & 0 & 0 & 0 & 0 & 0 & 0 & 0 & 0 & 0 & 0 & & 0 & 0 & 0 \\
\hline 16 & Depkeu & 0 & 0 & 0 & 0 & 0 & 0 & 0 & 0 & 0 & 0 & 0 & 0 & 0 & 0 & 0 & & 0 & 0 \\
\hline 17 & Mabes TNI & 0 & 0 & 0 & 0 & 0 & 0 & 0 & 0 & $\mathbf{1}$ & $\mathbf{1}$ & 0 & 0 & 0 & 0 & 0 & 0 & 0 \\
\hline
\end{tabular}

Keterangan(Remarks): Angka 1 = hubungan terkonfirmasi (confirmed relation), 0 = hubungan tidak terkonfirmasi (unconfirmed relation) 


\section{B. Administratif}

Hubungan administratif antar organisasi biasanya melibatkan transaksi sumber daya yang memungkinkan organisasi tersebut lebih efektif dalam mencapai tujuannya (Bolland dan Wilson, 1994). Hasil analisis pada aspek ini melihat seberapa jauh organisasi-organisasi yang terlibat dalam pengendalian kebakaran hutan/lahan saling membantu dalam pencapaian tujuan.

Di tingkat nasional, dari 22 organisasi yang diamati terdapat 15 organisasi yang saling membantu dalam pencapaian tujuan. AsdepPKHL dan Dit.PKH memiliki hubungan terbanyak dalam aspek tersebut. Di daerah, hubungan administratif dalam satu tingkatan baik di tingkat provinsi maupun di tingkat kabupaten/ kota sudah lebih terjalin di Riau daripada di Kalbar. Di Riau, organisasi-organisasi yang diamati telah memiliki hubungan administratif antar tingkatan mulai dari tingkat tingkat kabupaten/ kota sampai dengan tingkat nasional. Sementara itu, di Kalbar hubungan administratif terjadi hanya antara tingkat nasional dengan tingkat provinsi dan tingkat nasional dengan kabupaten/kota, sedangkan antara tingkat provinsi dan tingkat kabupaten/kota serta di antara organisasi-organisasi di satu tingkatan tidak ada hubungan (Gambar 3).

Kondisi tersebut menegaskan kembali pengaruh sistem pengorganisasian yang diterapkan di masing-masing daerah tersebut. Hal ini juga dapat menggambarkan fakta di mana sering terjadi organisasi di tingkat kabupaten/ kota berhubungan langsung dengan organisasi di tingkat nasional tanpa melalui organisasi di tingkat provinsi, misalnya ketika terjadi kebakaran hutan/lahan atau bencana alam.

Hasil analisis tersebut juga menunjukkan bahwa organisasi yang menangani kehutanan yang selama ini dipandang sebagai penanggung jawab atau pengelola kebakaran hutan/lahan ternyata tidak memiliki hubungan dengan organisasi-organisasi lain baik bantuan layanan maupun administratif. Dit. PKH Kementerian Kehutanan, Dishut Prov dan Dinas yang menangani kehutanan baik di Riau maupun di Kalbar ternyata tidak saling terhubungkan. Keadaan tersebut menunjukkan bahwa koordinasi yang merupakan pengelolaan saling ketergantungan (Malone et al., 1999) dan transaksi sumber daya (Bolland dan Wilson, 1994) untuk mencapai tujuan belum terjalin. Dengan perkataan lain, organisasi-organisasi tersebut belum saling mendukung dalam pencapaian tujuan atau masih berjalan sendirisendiri.

Hal ini dapat memberikan jawaban mengenai masih rendahnya kinerja pengorganisasian pengendalian kebakaran hutan/ lahan sampai sekarang. Kondisi demikian sebenarnya ditangani dengan melakukan aktivitas tambahan yang disebut coordination mechanisms (Malone dan Crowston, 1994). Pertama adalah menyepakati tujuan bersama, kemudian membagi tugas, mengidentifikasi sumber daya untuk menjalankan tugas, mengidentifikasi sumber daya yang harus dimiliki atau disediakan oleh organisasi mana, dan prosedur mobilisasinya.

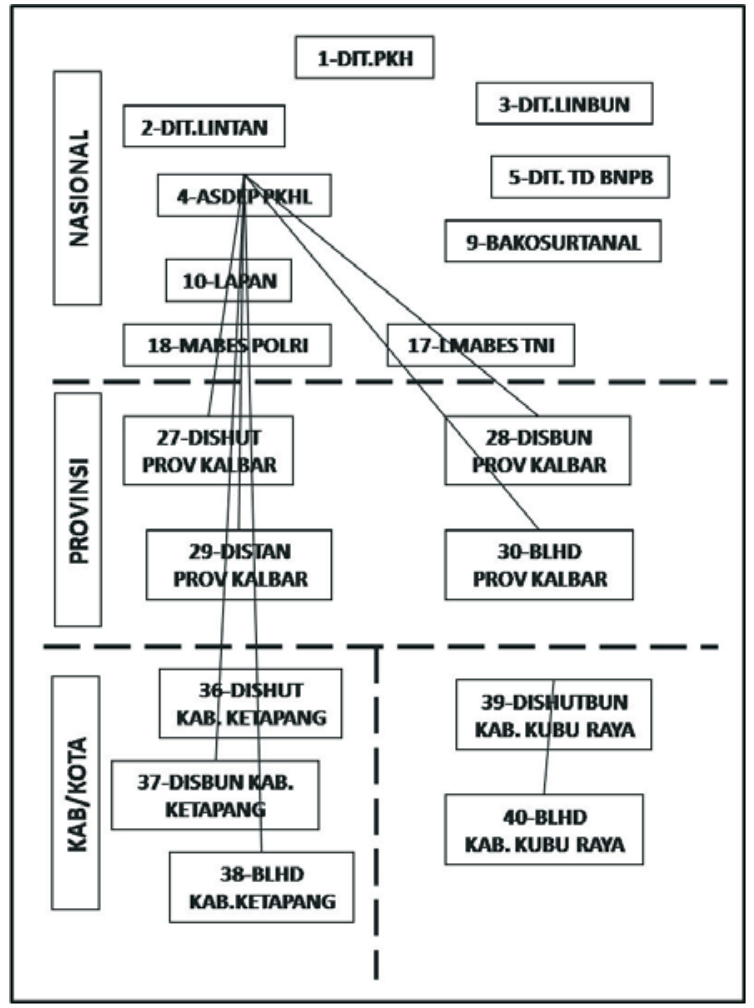

Gambar(Figure)3. Hubungan administratif antar organisasi antar tingkatan di Kalimantan Barat (Relationships on administrative aspect among levels in West Kalimantan)

\section{Perencanaan}

Hasil analisis terhadap aspek perencanaan (planning/agenda setting) menunjukkan bahwa di tingkat nasional hampir seluruh organisasi yang diamati, sedikitnya satu pimpinannya telah saling mengenal. Hal ini berarti dari aspek pertukaran gagasan, penetapan isu (agenda setting) 
maupun perencanaan telah terjadi hubungan yang relatif baik.

Di tingkat provinsi, hubungan para pihak di Riau relatif lebih baik, yang diindikasikan dengan lebih banyaknya pihak yang saling mengenal daripada yang terjadi di Kalbar. Sedangkan di tingkat kabupaten/kota, baik di Kab. Inhu, Kota Dumai, Kab. Kubu Raya maupun Kab. Ketapang, secara umum instansiinstansinya kurang saling mengenal.

Hubungan antar organisasi antar tingkat nasional, provinsi dan kabupaten/kota di Riau juga relatif lebih baik daripada di Kalbar. Meskipun hubungan berjalan satu arah, para pimpinan organisasi di tingkat kabupaten/kota di Kota Dumai dan Kab. Inhu, Provinsi Riau telah mengenal para pimpinan organisasi di tingkat provinsi maupun tingkat nasional (Gambar 4). Hal tersebut tidak terjadi di Kalbar.

Menurut Janssen, 2005), rendahnya tingkat perkenalan di antara organisasi akan menimbulkan kurangnya komunikasi dan keterlibatan secara emosional yang pada dasarnya berdampak pada rendahnya produktivitas organisasi (Janssen, 2005).

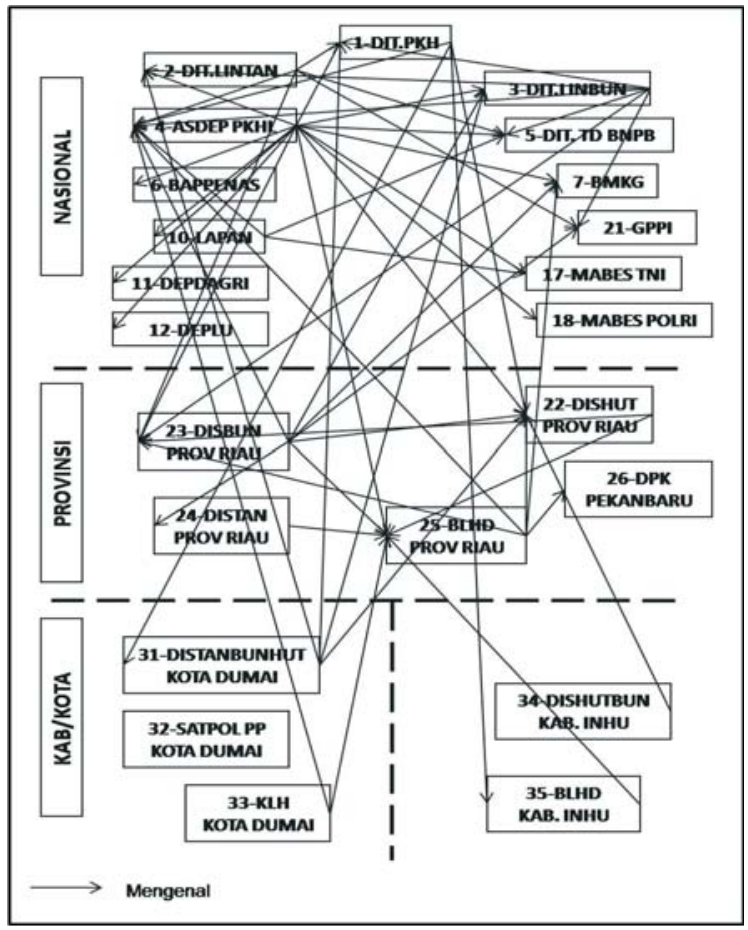

Gambar(Figure) 4. Hubungan antar organisasi dalam perencanaan di Riau (Interorganizational relationships on planning aspect in Riau)

Satu lagi hal penting dari kajian terhadap ketiga aspek tersebut di atas yaitu fakta bahwa ternyata tidak ada hubungan yang terjadi antar kabupaten/kota meskipun dalam satu provinsi. Hasil analisis terhadap ketiga aspek tersebut di atas menunjukkan bahwa koordinasi terpadu (Bolland dan Wilson, 1994) di antara organisasiorganisasi yang terlibat dalam pengendalian kebakaran hutan/lahan baik dalam satu tingkatan maupun antar tingkatan masih relatif kurang erat. Di sisi lain, keterpaduan kebijakan atau policy integration (Meijers dan Stead, 2004) juga sulit dibangun karena konsep keterpaduan dan "kemenyeluruhan" (comprehensiveness) belum menjadi acuan. Kondisi demikian menjadi salah satu faktor penting yang menyebabkan penanganan kebakaran hutan/lahan belum optimal.

Beberapa hal yang menyebabkan ketidakharmonisan hubungan antar organisasi dalam pengendalian kebakaran hutan/lahan adalah:

1. Di tingkat nasional belum terbentuk secara formal organisasi yang menangani pengendalian kebakaran hutan/lahan. Organisasi yang pernah ada, yakni Pusdalkarhutnas dan TKN-PKHL (Tim Koordinasi Nasional Penanggulangan Kebakaran Hutan dan Lahan), sudah tidak berlaku lagi sejak era Reformasi. Pembentukan Badan Nasional Penanggulangan Bencana (BNPB) berdasarkan Undang-undang No. 24/2007 tentang Penanggulangan Bencana, yang memasukkan kebakaran hutan/lahan sebagai jenis bencana, belum secara eksplisit mengakomodasikan kepentingan pengendalian kebakaran hutan/ lahan.

2. Di tingkat provinsi dan tingkat kabupaten/ kota, organisasi yang menangani kebakaran hutan/lahan (Pusdalkarhutlada dan Satlakdalkarhutlada) tidak termasuk sebagai SKPD (satuan kerja perangkat daerah) yang menurut UU No. 33/2004 tidak dapat mengelola anggaran, sehingga tidak dapat berfungsi dengan baik.

3. Anggaran untuk pengendalian kebakaran hutan/lahan berada pada SKPD, tetapi pada setiap SKPD terjadi pembatasan jumlah jabatan yang mendorong penetapan prioritas masalah yang lebih tajam, dan kebakaran hutan/lahan belum menjadi masalah prioritas, sehingga hanya beberapa SKPD yang memasukkan kebakaran hutan/lahan sebagai salah satu jabatan dalam strukturnya atau dalam kegiatannya.

4. Pergantian pimpinan yang relatif cepat atau jangka waktunya pendek baik di dalam masing-masing organisasi maupun antar 
organisasi membuat para pimpinan organisasi kurang berkesempatan untuk saling mengenal dan bersama-sama menyusun dan menyepakati serta memahami tata hubungan kerja atar organisasi.

5. Kurangnya komunikasi dan pertemuanpertemuan antar organisasi. Komunikasi atau pertemuan biasanya bersifat responsif ketika terjadi situasi darurat kebakaran hutan/lahan.

6. Kurang jelasnya uraian tugas dan tidak ditetapkannya pejabat tertentu untuk menangani kebakaran hutan/lahan di tiap organisasi serta kebiasaan mewakilkan pada staf untuk menghadiri pertemuan antar organisasi membuat penanganan masalah kebakaran hutan/lahan di tiap organisasi tidak fokus dan para pejabat/pimpinan organisasi tidak saling mengenal.

\section{Implikasi Terhadap Kebakaran Hutan/ Lahan}

Kondisi hubungan antar organisasi yang masih kurang harmonis baik dalam satu tingkatan maupun antar tingkatan tersebut di atas berimplikasi terhadap penanganan kebakaran hutan/lahan. Penanganan kebakaran hampir tidak mungkin dilakukan sendirian oleh masingmasing organisasi karena masih sangat lemahnya kapasitas organisasi. Hasil penelitian menunjukkan bahwa sumber daya (manusia dan sarpras) pada instansi-instansi yang terlibat dalam pengendalian kebakaran pada umumnya tidak tersedia secara memadai, baik di tingkat provinsi maupun kabupaten/kota.

Berdasarkan kondisi sumber daya yang terbatas tersebut maka perlu adanya kerja sama antar organisasi yang efektif dan efisien, karena sebuah organisasi tunggal tidak dapat mengatasi permasalahan masa kini yang kompleks, sekalipun memiliki sumber daya yang mencukupi (Mulford dan Klonglan, 1982). Organisasiorganisasi tersebut perlu membentuk jejaring yang kuat dengan peranan-peranan koordinasi (coordination roles) yang jelas (Wehmeyer et al., 2001). Pusdalkarhutlada dan Satlakdalkarhutla memang sudah ada, tetapi belum menjadi jejaring yang kuat karena koordinasi yang masih lemah.

Koordinasi adalah suatu upaya untuk mengelola ketergantungan di antara berbagai pihak, dan salah satu bentuknya adalah berbagi sumber daya (Malone et al., 1999). Koordinasi di antara organisasi yang terlibat dalam Pusdalkarhutlada atau Satlakdalkarhutla lemah karena hampir tidak ada sumber daya untuk berbagi.
Di samping SDM dan sarpras yang masih sangat kurang, dana atau anggaran untuk pengendalian kebakaran hutan/lahan juga belum tersedia. Pusdalkarhutlada maupun Satlakdal-karhutla di lokasi penelitian belum termasuk Satuan Kerja Perangkat Daerah (SKPD) sehingga tidak dapat memperoleh dan mengelola anggaran dan akibatnya operasionalnya sangat bergantung pada ketersediaan anggaran di instansi-instansi anggotanya. Sementara itu, hanya beberapa instansi anggota yang memiliki anggaran untuk kebakaran hutan/lahan dalam jumlah yang relatif sangat kecil, apalagi untuk digunakan berbagi dengan instansi-instansi lain. Kondisi inilah yang menyebabkan penanganan kebakaran hutan/lahan menjadi kurang optimal sehingga frekuensi kejadian kebakaran tetap relatif tinggi.

Prosedur kerja sama antar organisasi untuk pengendalian kebakaran hutan/lahan pada tingkat provinsi dan kabupaten/kota sebenarnya juga sudah ada di Riau dan Kalimantan Barat (Kalbar) yang ditetapkan masing-masing dengan Peraturan Gubernur (Pergub) Riau No. 91/2009 dan Pergub Kalbar No. 103/2009. Sayangnya, kedua Pergub tersebut tidak menjelaskan mekanisme pendanaan bagi kerja sama tersebut sehingga kerja sama tetap sulit untuk dilaksanakan.

\section{KESIMPULAN}

Berdasarkan kajian terhadap hubungan antar organisasi yang terlibat dalam pengendalian kebakaran hutan/lahan, maka dapat disimpulkan:

1. Bantuan layanan di antara organisasi dalam pengendalian kebakaran belum efektif baik di tingkat nasional, provinsi maupun kabupaten/ kota.

2. Pada aspek administratif, hubungan antar organisasi telah terjalin cukup baik di tingkat nasional, tetapi masih lemah di tingkat provinsi dan tingkat kabupaten/kota maupun antar tingkatan.

3. Hubungan antar organisasi pada aspek perencanaan juga terjalin baik di tingkat nasional, namun masih lemah di tingkat provinsi maupun tingkat kabupaten/kota.

4. Rendahnya tingkat jejaring kerja dan sumber daya (manusia, sarana dan prasarana, serta anggaran) di setiap organisasi yang terlibat dalam pengendalian kebakaran hutan/lahan berimplikasi besar pada penanganan kebakaran hutan/lahan. 


\section{DAFTAR PUSTAKA}

Bakry, L. 2009. Pengaturan Kedudukan Gubernur Sebagai Wakil Pemerintah di Daerah. Dalam: Ramses AM. dan Bakry L, editor. Pemerintahan Daerah di Indonesia. Jakarta: Masyarakat Ilmu Pemerintahan Indonesia. hlm 264-277.

[Bappenas] National Development Planning Agency. 1999. Planning for Fire Prevention and Drought Management in Indonesia, Final Report Volume 1. Jakarta: Bappenas.

Bolland, J.M. dan J.V. Wilson. 1994. Three Faces of Integrative Coordination: A Model of Interorganizational Relations in Communit-Based Heath and Human Services. Dalam Health Services Research 1994; 29-3:341-366.

Chandrasekharan, C. 1999. The Mission on Forest Fire Prevention and Management to Indonesia and Malaysia (Serawak): Tropical forest fire: prevention, control, rehabilitation and trans-bundary issues. (Nugroho, A. et al. editor). Proceedings International Cross Sectoral Forum on Forest Fire Management in South East Asia. National Development Planning Agency, Republic of Indonesia/JICA and ITTO. Jakarta, pp 204-282

Colman, A.W. dan J. Han. 2010. Organizational Roles and Players. http://www.ict.swin. Edu.au/personal/acolman/pub/ColmanA AAI_FS05.pdf. Diakses tanggal 29 Okt 2010.

[DFID] Department for International Development and World Bank. 2007. Working Paper: Indonesia and Climate Change Current Status and Policies. www.peace.co.id [27 Jan 2009]

Doscemascolo, G.P. 2004. Burning Issues: Control of Fire Management in Central Kalimantan, Indonesia. Disertasi. Hawaii, AS: The Graduate Division on the University of Hawaii.

Faerman, S.R., D.P. McCaffrey dan D.M.A. Slyke. 2001. Understanding Interorganizational Cooperation: Public-Private Collaboration in Regulating Financial Market Innovation (abstrack). Organization Science 2001; 12(3):372-388. http:// www.jstor.org/pss/3086014 [28 Jan 2009].
Hiroki, I dan D. Prabowo. 2003. Hasil Penggunaan Citra Satelit NOAA-AVHRR dan Himawari untuk deteksi Hot Spot di Stasiun Bumi Satelit NOAA-AVHRR/ Himawari FFPMP. Di dalam: Suratmo F.G, Husaeni EA, dan Surati Jaya N, editor. Pengetahuan Dasar Pengendalian Kebakaran Hutan. Bogor: Fakultas Kehutanan IPB. hlm 259-270

Hoessein, B. 2009. Hubungan Pusat dan Daerah Dalam Konteks Pemerintahan Umum. Dalam: Ramses AM, Bakry L, editor. Pemerintahan Daerah di Indonesia. Jakarta: Masyarakat Ilmu Pemerintahan Indonesia. hlm 218-222.

Janssen, M.A. 2005. Evolution of Instutional Rules: An Immune System Perspective. Willey Periodicals, Inc., 11(1):16-23

Kartodihardjo, H. 2006. Refleksi Kerangka Pikir Rimbawan Menguak Masalah Institusi dan Politik Pengelolaan Sumberdaya Hutan. Bogor: Himpunan Alumni Fakultas Kehutanan Institut Pertanian Bogor.

Malone, T.W., K. Crowston., J. Lee., B. Pentland., C. Dellarocas., G. Wyner., J. Quimby., C.S. Osborn., A. Bernstein., G. Herman., M. Klein., dan E. O'Donnell. 1999. Tools for Inventing Organizations: Toward a Handbook of Organizational Processes. Management Science 1999; 45-3:425-443.

Malone, T.W. dan K. Crowston. 1994. The Interdisciplinary Study of Coordination. Computing Surveys 26(1):87-119.

Meijers, E. dan D. Stead. 2004. Policy integration: what does it mean and how can it be achieved? A multi-disciplinary review. 2004 Berlin Conference on the Human Dimensions of Global Environmental Change: Greening og Policies - Interlinkages and Policy Integration. http:// web.fu-berlin.de/ffu/akumwelt/bc2004/ download/meijers_stead_f.pdf. Diakses tanggal 22 Jan 2009.

Mooi, E.A. 2007. Inter-organizational Cooperation, Conflict, and Change. Disertasi. Vrije Universiteit Amsterdam. Http://dare.ubvu. Vu.nl/bitstream/1871/ 12681/5/7725.pdf, Diakses tanggal 28 Jan 2009. 
Mulford, C.L. and G.E. Klonglan. 1982. Creating Coordination Among Organizations:an orientation and planning guide North Central Regional Extension Publication 80. [Ames, Iowa : Cooperative Extension Service, Iowa State University].

Simorangkir, D. 2001. Tinjauan Singkat Kerangka Hukum dan Kelembagaan dalam Penanganan Kebakaran Hutan dan Lahan di Indonesia. Dalam Suyanto S., Permana R. P., Applegate G., dan Setijono D. (editor). 2001. Prosiding Seminar Sehari Kebijakan Pengelolaan Sumberdaya Alam dan Aktivitas Sosial Ekonomi dalam Kaitannya dengan Penyebab dan Dampak Kebakaran Hutan dan Lahan di Sumatera. Bogor: Proyek Penelitian Kebakaran Hutan dan Lahan ICRAF dan CIFOR.

Siswanto, H.B. 2009. Pengantar Manajemen. Jakarta: PT. Bumi Aksara

Suprayitno dan L. Syaufina. 2008. Pengendalian Kebakaran Hutan. Bogor: Pusat
Pendidikan dan Pelatihan Kehutanan dan Korea International Cooperation Agency.

Ulrich, D. 1997. Organizing Around Capabilities. Dalam: Hesselbein F. Goldsmith M. dan Bechard R., editor. 1997. The Organization of the Future. San Francisco: Jossey-Bass Pusblishers. hlm 189-196

Wehmeyer, K., K. Reimer. dan B. Schneider. 2001. Roles and Trust in Interorganizational Systems. Proceedings of the Eight Research Symposium on Emerging Electronic Markets (RSEEM 01), Maastricht, The Netherlands. Http:// www-i5.informatik.rwth-aachen.de/ conf/ rseem2001/. Diakses tanggal 29 Okt 2010.

Young Lee, S. dan A.B. Whitford. 2008. Government Effectiveness in Comparative Perspective. http://ssrn.com/abstract= 1081642. Diakses tanggal 08 Mei 2008. 